\title{
OVULATION, CORPORA LUTEA DEVELOPMENT AND PITUITARY LH ACTIVITY IN RABBITS WITH INTRA-UTERINE DEVICES
}

\author{
K. JANAKIRAMAN AND L. E. GASIDA \\ Genetics Laboratory, University of Wisconsin, Madison, Wisconsin, U.S.A. \\ (Received 28th March 1967, revised 20th July 1967)
}

Summary. Sixty-eight oestrous New Zealand white rabbits were used in four experiments to study the pituitary LH content, ovulation time and corpus luteum development in the presence of intra-uterine devices (IUD) fitted in both horns. The results indicate that the IUD-fitted animals ovulate later and their pituitary LH content following mating is higher than in sham-operated controls. Also, such animals have lighter and less luteinized corpora lutea compared with their sham-operated controls at $24 \mathrm{hr}$ after mating.

\section{INTRODUCTION}

An intra-uterine device or devices (IUD) exert contraceptive actions in various species, but the mode of action varies. Adams \& Eckstein (1965) showed, in the rabbit, that the presence of an IUD in a uterine horn interfered with implantation in that horn and resulted in high embryo mortality. Ledger \& Bickely (1966), in the same species at 36 to 48 hours after mating, found no effect of the IUD on the number of ovulations. However, they did find myometrial changes in the treated uterine horn.

That an IUD may affect the release of luteinizing hormone $(\mathbf{L H})$ is suggested by the observation of Buch, Shukla \& Hawk (1964) that ovulation failed to occur in Indian water buffaloes fitted with plastic coils. Also Ginther, Pope \& Casida (1965) noted that the presence of IUD in sheep during the formative stages of the corpus luteum (CL) shortened their functional life and Stormshak \& Hawk (1966) showed that this action could be prevented by injection of HCG. Ginther, Hawk \& Casida (1966) examined the LH activity of the anterior pituitary in ewes at oestrus and at 3 days post-oestrus and found slightly higher levels in IUD-fitted animals. The present work concerns the effect of an IUD on the release of luteinizing hormone. Levels of pituitary LH before and accompanying ovulation are studied in IUD-fitted rabbits in which timing of the ovulation stimulus can be controlled precisely.

\section{MATERIALS AND METHODS}

New Zealand white rabbits, 7 to 13 months of age, were used in all studies. Females that showed typical lordosis when exposed to males were considered in heat and used in experiments. 


\section{Experimental series}

Experiment 1 . Twenty recently puberal rabbits, 7 to 9 months of age, were allotted randomly to four groups of five each and treated as follows: (1) IUD inserted in each uterine horn, non-mated; (2) sham-operated, non-mated controls; (3) IUD inserted in each uterine horn, mated; (4) sham-operated, mated controls. The females to be fitted with IUD were anaesthetized with pentobarbital sodium ('Anesthesal', Norden Laboratories), injected into the ear vein on the day they were found in heat (Day 1) and laparotomized (mid-ventral incision). A polyethylene plastic spiral (IUD) of $7 \mathrm{~mm}$ outer diameter and $25 \mathrm{~mm}$ length was inserted into the upper end of each uterine horn through an incision approximately one third of its length from the tubo-uterine junction. A synthetic surgical suture ('Vetafil', Bengen \& Co.), was placed through the lips of the incision and one turn of the spiral, thus closing the incision and securing the spiral in position at the same time. The sham-operated controls were subjected to similar surgical procedures as the treated ones. An incision was made into each uterine horn and sutured without IUD insertion.

Mated animals were killed $24 \mathrm{hr}$ after mating (Day 5). The non-mated ones were also killed on the same day relative to surgery. Pituitary glands were removed and the anterior lobes dissected out, weighed and frozen for LH assay. During the course of autopsy, a decision was made to dissect out the corpora lutea (CL) and weigh them.

Experiment 2. Eight rabbits, 7 to 9 months of age, were assigned randomly to two groups of four each. Females of one group were fitted with an IUD in each horn and mated on Day 4 following insertion. Females of the other group served as sham-operated, mated controls. All females were laparotomized $11 \mathrm{hr}$ following mating; ovulation points and follicles of $1 \mathrm{~mm}$ or more in diameter were counted. These rabbits were killed $24 \mathrm{hr}$ following mating to obtain the final number and weight of CL.

Experiment 3. Twenty rabbits, 10 to 13 months of age, were divided into four groups as in Expt. 1. The treatments and killing time were the same as in Expt. 1, except that the weighing and histological examination of the CL at $24 \mathrm{hr}$ p.c. was pre-planned. The anterior pituitary glands were assayed for LH activity.

Experiment 4. Twenty rabbits, 10 to 13 months of age, were divided randomly into two groups of ten each. One group received an IUD in each horn on the day of heat, mated on Day 4 following IUD insertion and killed $11 \mathrm{hr}$ following mating. The other group served as sham-operated, mated controls and also was killed $11 \mathrm{hr}$ following mating.

\section{LH assay procedures}

The relative pituitary LH activity in all the experiments was measured by the ovarian ascorbic acid depletion method of Parlow (1961), using Holtzman rats. Each pituitary gland was assayed individually. Two rats per dose and three doses per gland were used. The freshly-frozen, stored pituitary glands were homogenized in physiological saline about $10 \mathrm{hr}$ before injection into assay rats. The suspensions of homogenized glands were centrifuged and the supernatants were collected and stored at refrigerator temperature. They were then diluted 
so that the required dose was contained in $1 \mathrm{ml}$ about half an hour before being injected into Parlow rats. Doses of 1,2 and $4 \mathrm{mg}$ were used in Expt. 1 and 0.75, 1.5 and $3 \mathrm{mg}$ in Expt. 3 and 4. The extracts were injected into the tail vein and the rats were killed $4 \mathrm{hr}$ later. The ovaries were then removed, weighed and processed to estimate the ovarian ascorbic acid content (Mindlin \& Butler, 1938).

\section{Statistical analysis}

Analysis of variance and Duncan's multiple range test were used to analyse the data (Steel \& Torrie, 1960). The ascorbic acid content was adjusted for ovarian weight by covariance analysis (Sakiz \& Guillemin, 1963). The bioassay was considered valid inasmuch as there was a significant overall linear dose-response relationship (Bliss, 1952) and there was no significant deviation from linearity of regression. There was nonparallelism of regression lines in Expt. 3, the lesser regression being shown by the treatment group showing the greater OAA depletion which is to be expected in instances approaching a maximum depletion. Relative potencies were calculated using the mean doseresponse for the whole experiment as the standard.

\section{RESULTS AND DISGUSSION}

The objective of Expt. 1 was to explore for possible IUD effects on LH potency of the pituitary gland both before mating and $24 \mathrm{hr}$ after when the LH levels were presumed to be near their lowest point (Hill, 1934). The respective relative potencies of control and IUD-treated groups were found to be 2.03 and 1.71 before mating and 0.41 and 0.72 after mating (Table 1). The pituitary LH activity was lower in the two mated groups than in the non-mated groups

TABLE 1

PITUITARY LH AGTIVITY, NUMBER AND WEIGHT OF CL IN RABBITS FITTED WITH IUD AND GONTROLS (FIVE RABBITS/GROUP)

\begin{tabular}{|c|c|c|c|c|c|}
\hline Comparison & $\begin{array}{c}\text { No IUD } \\
\text { non-mated }\end{array}$ & $\underset{\text { non-mated }}{I U D}$ & $\begin{array}{c}\mathcal{N} \text { No IUD } \\
\text { mated }\end{array}$ & $\begin{array}{l}\text { IUD } \\
\text { mated }\end{array}$ & $\begin{array}{c}\text { Error* } \\
\text { mean square }\end{array}$ \\
\hline $\begin{array}{l}\text { Expt. I } \\
\text { OAA } \\
\text { LH potency } \\
\text { Av. No. CL } \\
\text { Av. CL wt. (mg) }\end{array}$ & $\begin{array}{c}75 \cdot 5^{a} \\
2 \cdot 03 \\
- \\
-\end{array}$ & $\begin{array}{c}77 \cdot 3^{\mathbf{a}} \\
1 \cdot 71 \\
- \\
-\end{array}$ & $\begin{array}{c}92 \cdot 5^{\circ} \\
0.41 \\
8.8 \\
1.67\end{array}$ & $\begin{array}{c}86 \cdot 5^{\mathrm{b}} \\
0 \cdot 72 \\
9 \cdot 6 \\
1 \cdot 20\end{array}$ & $\begin{array}{r}864 \\
- \\
- \\
-\end{array}$ \\
\hline $\begin{array}{l}\text { Expt. } 3 \\
\text { OAA } \\
\text { LH potency } \\
\text { Av. No. CL } \\
\text { Av. CL wt. (mg) }\end{array}$ & $\begin{array}{c}88 \cdot 6^{a} \\
1 \cdot 84 \\
- \\
-\end{array}$ & $\begin{array}{c}86 \cdot 7^{a} \\
2 \cdot 01 \\
- \\
-\end{array}$ & $\begin{array}{c}124 \cdot 7^{\mathrm{c}} \\
0 \cdot 33 \\
10 \cdot 2^{\mathrm{a}} \\
4 \cdot 12^{\mathrm{a}}\end{array}$ & $\begin{array}{c}105 \cdot 7^{\mathrm{b}} \\
0 \cdot 82 \\
10 \cdot 6^{\mathrm{a}} \\
3 \cdot 21^{\mathrm{b}}\end{array}$ & $\begin{array}{l}927 \\
- \\
5 \cdot 5 \\
0 \cdot 38\end{array}$ \\
\hline
\end{tabular}

Means on the same horizontal line with same superscript are not significantly different from each other at $P<0.05$ as tested by Duncan's multiple range test using variation between rabbits as the error term.

$\mathrm{OAA}=$ Mean ascorbic acid content, $\mu \mathrm{g}$, for ovaries of thirty test rats (five pituitary glands, three doses/gland and two rats/dose).

$\mathrm{LH}$ potency $=$ potency relative to the average of the glands in the experiment which was used as a standard.

* Mean square between rabbits within treatments.

C 
$(P<0 \cdot 05)$. It was noted during the autopsy of the mated animals that the $\mathrm{cr}$ appeared to be larger in the controls than in the IUD group. An unweighted average of the mean individual CL weights for the different rabbits was found to be 1.67 and 1.20, respectively. The weighing of CL was not planned ahead of time but the results appeared inconsistent with the observations of Ginther (personal communication) that IUDs in rabbits did not affect cL weight when observed 10 to 14 days after ovulation.

Experiment 2 was designed to study the number of ovulations at $11 \mathrm{hr}$ as well as at $24 \mathrm{hr}$. There were averages of 6.75 follicles and 0.50 ovulations in the IUD group as compared with 1.00 follicles and 7.75 ovulations in the control group $11 \mathrm{hr}$ p.c. (Table 2). The unovulated follicles present at $11 \mathrm{hr}$ p.c. were repre-

TABLE 2

PITUITARY LH AGTIVITY, NUMBER OF FOLLICLES AND CL FOLLOWING MATING IN RABBITS FITTED WITH IUD AND CONTROLS

\begin{tabular}{|c|c|c|c|c|c|}
\hline Comparison & \multicolumn{2}{|c|}{$11 \mathrm{hr}$ after mating } & \multicolumn{2}{|c|}{$24 \mathrm{hr}$ after mating } & $\begin{array}{c}\text { Error* } \\
\text { mean square }\end{array}$ \\
\hline $\begin{array}{l}\text { Expt. } 2 \\
\text { Av. No, GL } \\
\text { Av. No. folliclest }\end{array}$ & $\begin{array}{l}7 \cdot 75 \\
1 \cdot 00\end{array}$ & $\begin{array}{l}0.50^{* *} \\
6.75^{* *}\end{array}$ & $\begin{array}{l}8.75 \\
0.00\end{array}$ & $\begin{array}{l}6 \cdot 25 \\
1.00\end{array}$ & $\begin{array}{l}6.5 \\
0.75\end{array}$ \\
\hline $\begin{array}{l}\text { Expt. } 4 \\
\text { Av. No. CL } \\
\text { Av. No. folliclest } \\
\text { OAA } \\
\text { LH potency }\end{array}$ & $\begin{array}{c}8 \cdot 6 \\
1 \cdot 3 \\
118 \cdot 7 \\
0 \cdot 54\end{array}$ & $\begin{array}{c}1 \cdot 4 * * \\
9 \cdot 4 * * \\
92 \cdot 2 * * \\
1 \cdot 85\end{array}$ & $\begin{array}{l}- \\
- \\
- \\
-\end{array}$ & $\begin{array}{l}- \\
- \\
- \\
-\end{array}$ & $\begin{array}{l}- \\
- \\
- \\
-\end{array}$ \\
\hline
\end{tabular}

** $P<0.01$ for difference from control.

$\dagger$ Follicles $1 \mathrm{~mm}$ or more in diameter.

$\mathrm{OAA}=$ Mean ascorbic acid content, $\mu \mathrm{g}$, for ovaries of sixty test rats (ten pituitary glands, three doses/gland and two rats/dose).

LH potency $=$ Potency relative to the average of the glands in the experiment which was used as a standard.

* Mean square between rabbits within treatments.

sented by an equal number of ovulations $24 \mathrm{hr}$ p.c. in the control group and the average number of follicles had declined to 1.00 from 6.75 in the IUD group.

Experiment 3 was planned to study pituitary LH activity and number and weight of CL at $24 \mathrm{hr}$ p.c. in more mature rabbits than were used in Expt. 1. The relative potency of pituitary LH was 0.33 in the mated control group and 0.82 in the mated IUD group $(P<0.05)$. The difference between IUD and control non-mated groups, 2.01 and $1 \cdot 84$, was not statistically significant (Table 1). No difference was found in the number of CL in the two mated groups, but there was a difference in their average weight $(P<0 \cdot 05)$. Histological observation of the cL also indicated less intense luteinization in the IUD mated group.

Experiment 4 was designed to compare pituitary LH activity and ovulation rate $11 \mathrm{hr}$ following mating in control and IUD-treated groups. The relative pituitary LH potency was 1.85 in the IUD mated group as against 0.54 in the mated control group $(P<0 \cdot 01)$. Also there was a marked difference in the 
number of $\mathrm{CL}$ and follicles in the IUD-treated group, 9.4 follicles and 1.4 ovulations, and in the control group, 1.3 follicles and 8.6 ovulations.

The results noted in Expt. 1 suggested that cL in the IUD mated group were lighter than in the control mated group. This could have been a chance occurrence, noted after the fact, or it might have indicated that the animals with an IUD ovulated late or that the development of the CL was inhibited by the presence of the IUD. The results in Expt. 2 clearly demonstrated that the IUD mated group ovulated late. However, $24 \mathrm{hr}$ after mating there was no difference in the number of ovulations.

The fact that pituitary LH activity in the IUD mated groups was higher in all three experiments indicates that the presence of an IUD in both horns in these rabbits delayed LH release and thereby delayed ovulation time also. However, the presence of IUD in the absence of mating did not affect LH content of the pituitary gland.

\section{ACKNOWLEDGMENTS}

Paper number 1123 from the Genetics Laboratory published with the approval of the Director of the Agricultural Experiment Station. This study was done under a cooperative agreement between the Wisconsin Agricultural Experiment Station and the Dairy Cattle Research Branch, U.S.D.A. The work was supported in part by the Branch and also by a grant from the Ford Foundation.

\section{REFERENCES}

Adams, C. E. \& Eckstein, P. (1965) The effect of intrauterine foreign bodies on pregnancy in the rabbit. Fert. Steril. 16, 508.

Buss, C. I. (1952) The statistics of bioassay with special reference to vitamins. Academic Press, New York.

Buch, N. C., Shukra, K. P. \& HAwK, H. W. (1964) Interference with ovulation by intrauterine plastic devices in Indian water buffaloes. 5th int. Cong. Anim. Reprod. and Artif. Insem., Trento, 2, 242.

Ginther, O. J., Hawx, H. W. \& Casida, L. E. (1966) Pituitary LH activity of ewes treated with an intrauterine device. (Abstract). 7. Anim. Sci. 25, 1262.

Ginther, O. J., Pope, A. L. \& CASIDA, L. E. (1965) Some effects of intrauterine plastic coils in ewes. (Abstract). 7. Anim. Sci. 25, 472.

HILl, R. T. (1934) Variation in the activity of the rabbit hypophysis during the reproductive cycle. 7. Physiol., Lond. 83, 129.

Ledger, W. J. \& Bickely, J. E. (1966) Effect of a plastic foreign body on the genital tract of the female rabbit. Obstet. Gynec. 27, 685.

Mindlin, R. L. \& Butler, A. M. (1938) The determination of ascorbic acid in plasma: a macromethod and micromethod. 7 . biol. Chem. 122, 673.

PARLow, A. F. (1961) Bio-assay of pituitary luteinizing hormone by depletion of ovarian ascorbic acid. In: Human Pituitary Gonadotrophins. Ed. A. Albert. Thomas, Springfield, Illinois.

SAKIz, E. \& GuILlEmIN, R. (1963) On the method of ovarian ascorbic acid depletion as a test for luteinizing hormone (LH). Endocrinology, 72, 804.

Steel, R. G. D. \& Torrie, J. H. (1960) Principles and procedures of statistics. McGraw-Hill, New York.

Stormshak, F. \& Hawk, H. W. (1966) Effect of intrauterine spirals and HCG on the corpus luteum of the ewe. (Abstract). F. Anim. Sci. 25, 877. 